\title{
The Design, Funding, and Management of Infrastructure in Local Municipalities: A Study From Canada
}

\author{
Tom Cooper \\ Memorial University of Newfoundland \\ Pauline Downer \\ Memorial University of Newfoundland
}

\author{
Alex Faseruk \\ Memorial University of Newfoundland
}

\begin{abstract}
The design, funding, management of infrastructure is a challenge for organizations both large and small. Beyond size, when place-based issues such as demographics, geography, and climate are also considered strategic decisions around infrastructure are further complicated. The following study, based on 300 municipalities in the province of Newfoundland and Labrador in Canada, explores good practice and provides recommendations to improve municipal infrastructure in local towns and villages. Municipalities, as organizations, are an interesting area of study because they are multifaceted, socialpurpose entities with governance, strategic, and financial concerns, similar, but different to those of the private sector. Moreover, as with any organization, they are required to be managed, controlled, and financed. How they address their most important, and yet basic, strategic questions, specifically how, why, and when to invest in infrastructure, is important both for public policy and management research.
\end{abstract}

Keywords: municipalities, public investment, capital stock

\section{INTRODUCTION}

A comprehensive and coherent approach to the design, management and funding of the infrastructure that comprises local towns and villages, especially in rural areas, is needed. Urbanization and subsequent outmigration of citizens to larger cities has been occurring throughout the developed and developing world. This outmigration has meant the erosion of not only rural populations but also tax bases for local cities and towns. The following study, based on 300 municipalities in the province of Newfoundland and Labrador in Canada, explores good practice and provides recommendations to improve municipal infrastructure in local towns and villages.

Canadian municipalities in the form of cities, towns, villages, and otherwise unincorporated areas normally enjoy significant fiscal autonomy which they invest, among other things, in infrastructure. As a result, all municipalities, in varying ways design, manage, maintain, and fund infrastructure. Also, due to their fiscal autonomy, all municipalities must engage in the design, management, and funding of 
infrastructure; these activities are, therefore, of critical strategic and operational importance for all municipalities.

Municipal governments are local authorities created by the provinces and territories to provide services that are best managed under local control. Revenue (predominantly from property taxes and grants, mostly provincial) impact people's daily lives in several ways, from garbage pick-up and public transit to fire services, policing, programs in community centers, libraries, rinks, and pools. Municipal governments include cities, towns, villages and rural (county) or metropolitan municipalities (Plunkett, 2017). Municipality, in this case, is used to contrast with other local government organizations in the United States that operate under different legal and governance frameworks.

The type of infrastructure in municipalities varies depending on geographic location, legislation, as well as local policies and procedures. This paper explores critical success factors and barriers to the design, building, and funding of municipal infrastructure in the Canadian province of Newfoundland and Labrador. Choosing Newfoundland and Labrador is partially through convenience and because it contains a larger number of exceedingly small communities in a large geographic area with almost $90 \%$ of them rural. Municipalities in this province increasingly find themselves in uncertain times due to the impact of demographic shifts, uncertain financial arrangements, technology, and an ever-growing pace of change. These drivers represent enormous opportunities and hazards for municipalities, particularly around infrastructure. The consequences of the failure to adapt also pose significant risk on a go forward basis.

In Newfoundland and Labrador, as in most Canadian provinces, municipal infrastructure may potentially include fire halls, indoor swimming pools, arenas/rinks, and community centers. In some cases, municipal infrastructure may not extend beyond a town hall and include some industrial equipment. In other cases, municipalities, acting as service centers, may have a broad scope of infrastructure available to both their citizens and the surrounding community.

Newfoundland and Labrador also face demographic challenges, such as an aging population which requires public investment in infrastructure. The result is a dilemma: how to meet new and growing demand in public infrastructure while simultaneously addressing growing deficits and accumulated debt? One of the proposed solutions is to spend less on infrastructure. Spending reductions alone, however, will not solve a municipality's strategic issues. Attrition is a difficult model, and potentially a non-sustainable model, to ensure that the municipalities meet future demands for enhanced infrastructure.

Municipalities, as organizations, are an interesting area of study because they are multifaceted, socialpurpose entities with governance, strategic, and financial concerns, similar, but different to those of the private sector. Moreover, as with any organization, they are required to be managed, controlled, and financed. How they address their most important, and yet basic, strategic questions, specifically how, why, and when to invest in infrastructure, is important both for public policy and management research.

\section{REVIEWING MUNICIPAL INFRASTRUCTURE}

Municipal infrastructure is a difficult area to analyze because municipalities are not recognized in the Canadian constitution; they are dependent on the provinces for powers and responsibilities. Municipalities fall under provincial jurisdiction (L'heureux, 1986). Despite this constitutional situation, municipalities offer the majority of direct and essential services to the Canadian population, including fire protection, waste collection, administration of waste facilities, recycling programs, permit issuance, recreational activities, drinking water, collection and treatment of wastewater, and public transportation to name but some of the more important activities. They also enjoy a wide latitude in their granted fiscal autonomy. The services that are offered, as well as the fiscal autonomy, mean that municipal infrastructure is of vital strategic importance to the provinces and the country.

There are many different methods to explore the impact of municipal infrastructure. Analysis is further complicated by the scope of infrastructure within municipalities, particularly in Newfoundland and Labrador. Some municipalities in this province have extensive infrastructure within their town or city, others have little, existing infrastructure, which can be of varying age and usefulness. As well, the ability to maintain and fund infrastructure is more of a challenge for some communities than others. 
In Canada, as is the case in Newfoundland and Labrador, the infrastructure that is typically present in municipalities includes, but is not restricted to: roads, transit systems, utilities, bridges, water/sewage treatment plants, centers, and parks. Although there is a broad scope of infrastructure, it nonetheless needs to be designed, funded, and managed by municipalities. Time is also critical; municipal infrastructure projects are planned, developed, and financed over decades. From a planning perspective, a common practice is funding infrastructure projects in five-year increments and through ad hoc, unpredictable announcements. This approach that may limit their effectiveness, scope, and size. Design, management, and funding of infrastructure are all inter-related as long-term plans are needed to provide a framework for municipalities in their largely short-term operations, while meeting the more long-term strategic objectives

To address these concerns, a comprehensive and coherent approach to the design, management and funding of municipal infrastructure is needed both in Newfoundland and Labrador, as well as elsewhere in Canada. The purpose of this report is to examine good practices in the design, management, and funding of municipal infrastructure. At its conclusion, the report provides specific recommendations for municipalities to consider and address strategically the design, management, and funding of municipal infrastructure.

\section{APPROACH TO THE STUDY}

The study conducted a review of the sustainable good practices on how municipalities addressed design, manage, and fund of municipal infrastructure. The local association of municipalities, Municipalities Newfoundland and Labrador, partnered in the development of the study, as they required knowledge of the good practices to enhance their sustainability. In the review of good practice, the focus was on the processes by which municipalities best design, manage, and fund municipal infrastructure. Specifically, a best practice review was conducted around the strategic design, management, and funding of municipal infrastructure, resulting in the development of several models to aid in the explanation of how these good practices can be subsequently developed. Between 2016 and 2019, initial findings were presented at municipal conferences and symposiums involving Mayors, Councillors, Town Managers and staff on the good practices in the design, management, and funding of municipal infrastructure. In total, over 500 municipal leaders were engaged either directly or indirectly in discussing, developing, and validating the good practices around the design, management, and funding of municipal infrastructure.

Using content analysis and semi-structured interviews a participatory approach explored the question of the design, management, and funding of municipal infrastructure. Specifically, the research collated information on municipal infrastructure management practices, while addressing questions around design, management, and funding strategies. Through a series of semi-structured interviews and meetings with over 500 municipal leaders, a series of trends and emerging issues were indemnified and explored in detail. Finally, the potential barriers and key success factors to addressing the design, management and funding of municipal infrastructure were examined.

Overall, this study aims to provide concepts, models, and processes around infrastructure, which can be applied to various types of municipality, regardless of size. Moreover, the study serves to assist political leaders and municipal managers in understanding the principles required to effectively design, manage, and fund municipal infrastructure. It is not meant to provide specific, prescriptive procedures, some of which are currently being developed in a federal approach to asset management for municipalities, but rather to provides information on what a municipality should do to design, management, and fund municipal infrastructure. It is a guide on the how rather than the what of strategically designing, managing, and funding infrastructure for municipalities.

\section{CANADIAN AND NEWFOUNDLAND AND LABRADOR MUNICIPAL INFRASTRUTURE}

As outlined in Canada's Infrastructure Report Card (2016), development of Canada's public infrastructure has closely tracked that of the country, beginning in the early 1800 s with the first roads, 
canals, and later railways. By the early twentieth century, Canadian public works reflected the country's emerging industrial capacity. Electrification, safe drinking water, waste management, and public transit supported growing cities and communities.

The Golden Age of Canadian infrastructure followed the Second World War, and continued through the 1950s and 1960s, with significant investments in municipal infrastructure. In the 1970s and 1980s, however, government spending on public infrastructure declined in the face of competing priorities and the end of the post-war economic boom. The deferral of needed investment led to a decline in the physical condition of local infrastructure and an increase in the cost of renewing aging assets.

Trends in municipal infrastructure in Newfoundland and Labrador mimic those of the rest of Canada, significant investment in the post confederation years (Newfoundland and Labrador joined the Canadian Confederation in 1949) with pronounced declines over the last twenty years. Given these trends, flexibility in how the province of Newfoundland and Labrador and its municipalities plan, develop, and deliver its public sector infrastructure is key for the province's long-term success, given the existing infrastructure deficit, as well as continuing financial constraints. As well, there are both short- and longterm pressures on the province's economy. For example, as the price of oil and gas and other commodities continues to decline, the Newfoundland and Labrador economy is expected to contract in the short to medium term. As a result, it is difficult to design, manage, and finance infrastructure in an environment of fiscal uncertainty.

However, the municipal infrastructure deficit in Newfoundland and Labrador is a continuing concern. Municipalities in Newfoundland and Labrador have significant assets in their infrastructure: roads, sewers, and even the computer software to send out tax notices. In 2010, the last year that data were collected, there was $\$ 2.8$ billion invested in municipal infrastructure in the province of Newfoundland and Labrador. In aggregate, the level of municipal infrastructure in Newfoundland and Labrador is at \$2.8 billion with over $\$ 1.35$ billion in amortization. As a result, most of this infrastructure is ending its useful life and/or is considered fully amortized from an accounting viewpoint.

As part of this study, information was provided by the Department of Municipal Affairs of the province. In total, 269 communities Tangible Capital Asset reports were presented in a spreadsheet by asset classes http://www.ma.gov.nl.ca/ma/publications/psab/ref_materials/appendix_2_assets_classes.pdf, as well as in aggregate. There is a significant amount invested in municipal infrastructure in Newfoundland and Labrador. Some small, rural communities would seem to be some of the ones with the best (i.e. newest) infrastructure based on amortization to net book value. While other small, rural communities are the ones with their municipal infrastructure most at risk as they have a higher amortization to net book value ratio.

The importance of the St. John's CMA area, the capital of Newfoundland and Labrador, to the whole of the municipal infrastructure within the province cannot be overstated. Moreover, the major urban centres make up most of the value of the municipal infrastructure seen in Newfoundland and Labrador from a Net Book Value perspective. The same is true with the rest of Canada. A report card issued by the Canadian Federation of Municipalities in 2016, which surveyed more than 120 municipalities representing $90 \%$ of the Canadian population, stated that there are significant concerns around infrastructure. In the 2012 version of the study, it found that one in four roads is over capacity, transporting far more people and goods than it was designed to handle. And one in four wastewater treatment plants needs to be upgraded or replaced to meet new federal standards introduced this summer, at a cost of at least $\$ 20$ billion. http://www.canadainfrastructure.ca/en/report.html

In 2016, one-third of the municipal infrastructure is in fair, poor or very poor condition, increasing the risk of service disruption. The survey found that increasing reinvestment rates will stop the deterioration of municipal infrastructure and save money in the long-term. The 2016 provincial survey found that building for today's communities and tomorrow's Canada requires long-term planning and all communities, particularly smaller municipalities, would benefit from increased asset management capacity.

How municipalities and the province manage these infrastructure risks is an important question. Although in an ideal world there would be a steady stream of revenue from a growing tax base and 
continual major investment from provincial and federal governments, this scenario would in the medium to long term, seem unlikely. Municipalities can, however, better oversee the design, management, and funding of their municipal infrastructure through strategic planning and asset management.

\section{DESIGN}

In reviewing good practices, the effective design of municipal infrastructure is essential for these following enumerated reasons. First, good municipal design helps to minimize the impact on society in the case of severe disturbances.

Second, municipal infrastructure must be resilient to failures. Infrastructure must be able to continue operations or quickly recover a stable state after a major mishap. Numerous opportunities for taking measures to increase the resilience of municipal infrastructure emerge in the design stage.

Third, and arguably most importantly in the design stage, is determining service levels (International Infrastructure Management Manual 2011, p. 273). An essential good practice of designing municipal infrastructure is establishing the level of service that a municipality provides both now and in the future. The level of service is determined examining the interrelated elements, including asset understanding, consultation and communication, strategic alignment, risk, as well as financial considerations shown below in Figure 1 - Determining Service Levels for Municipal Infrastructure.

\section{FIGURE 1}

\section{DETERMINING SERVICE LEVELS FOR MUNICIPAL INFRASTRUCTURE}

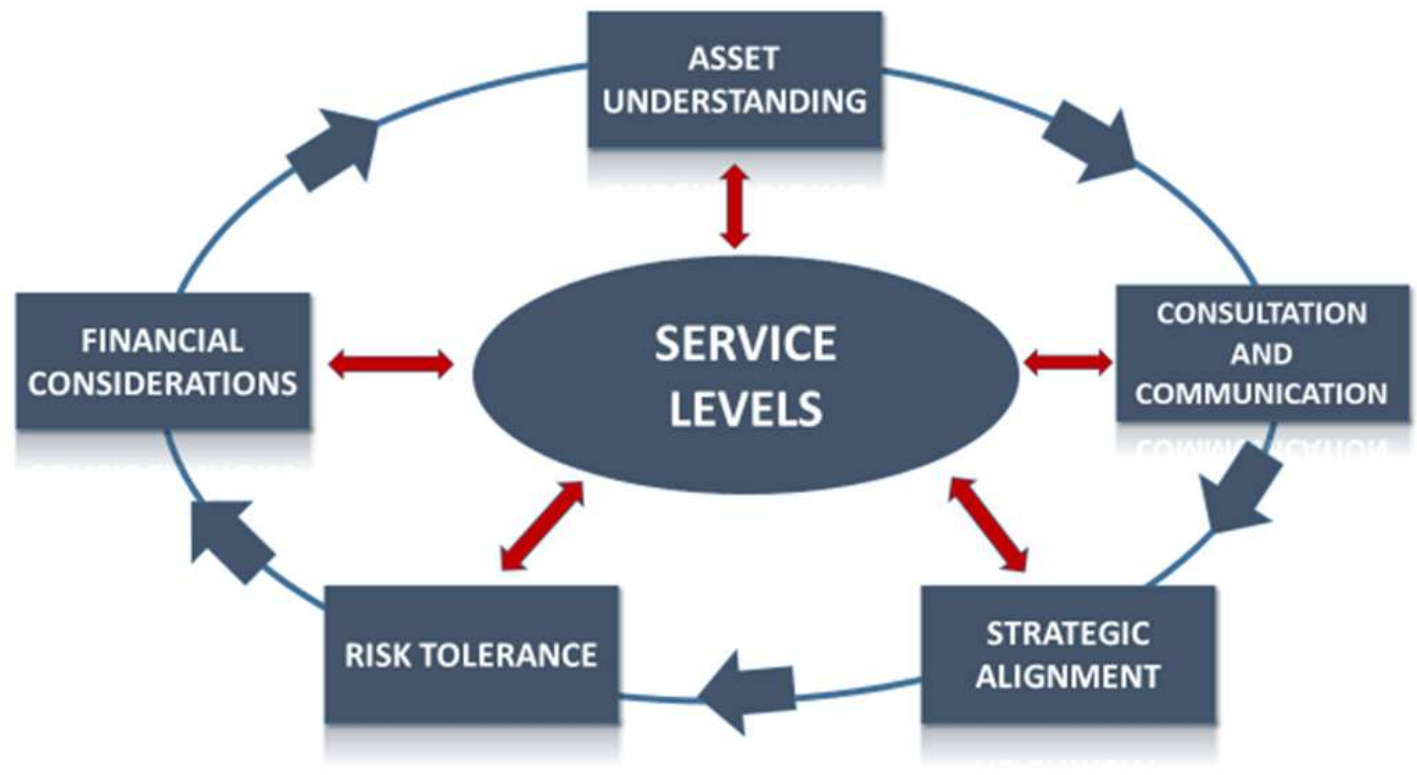

This figure was developed from:

https://www.fcm.ca/Documents/reports/Infraguide/Developing_Levels_of_Service_EN.pdf and http://www.cogta.gov.za/mig/docs/Municipal_Infrastructure_Roles_\&_Responsibilities.pdf

Service levels underlying municipal infrastructure can be understood by the following elements:

\section{Asset Understanding}

Asset understanding involves identifying existing municipal infrastructure (nature of, number, length, volume, location, etc.) and assessing its performance. 


\section{Consultation}

Consulting with the users of municipal infrastructure establishes perceptions of the acceptability of existing levels of service as well as user willingness to pay (directly or indirectly) for either a higher or lower service level. Consultation/communication includes the identification of key stakeholders and the effectiveness of current methods of obtaining user assessments of levels of service. Methods are then implemented to monitor user expectations.

\section{Strategic Alignment}

A municipality's strategic or operational goals, as reflected in the direction provided by elected officials and administration, generally sets the tone for the levels of service the community wants and its willingness/ability to support them financially.

\section{Risk Tolerance}

Risk surrounds a municipality and needs to be understood when decisions on levels of service are taken. The municipality must be aware of this exposure to risk and determine its level of comfort and willingness to accept that risk.

\section{Financial Considerations}

In many instances, the levels of service are dictated by user willingness to pay as well as the municipality's ability to maintain an acceptable level of service.

All these elements are difficult for a municipality to manage simultaneously. Tradeoffs will have to be made and are accomplished most effectively when there is a process of prioritization with clear goals and objectives. One of the critical success factors for effective design is therefore understanding the role of these trade-offs. Prioritization of trade-offs in the design stage of municipal infrastructure projects is accomplished through a clear, well-thought out process including:

\section{Weighting and Ranking Systems}

Weighting and ranking works best at the micro-level of decision making that often takes place at the departmental level, following a technical assessment or a decision made at Council. The method typically includes weighting factors in a prioritization system and, often, public input is of assistance in developing these factors. Qualitative criteria can include social, economic, and environmental goals since the criteria are often related to a municipality's strategic objectives.

\section{Linking Capital With Operations and Maintenance (O\&M) Budgets}

Linking capital with O\&M budgets is a prioritization process that examines the full life-cycle cost of a capital investment and any estimated increases or decreases in the operation and maintenance budget. In this prioritization process, full costs are identified in the design, maintenance/replacement decisions as well as for new infrastructure. This allows the municipality to plan more accurately for future operating and capital budget allocations as well as avoid chronic budget shortfalls. A municipality is then able to make better decisions regarding capital project planning. Projects are only allowed to go ahead once the entire projected cost, including maintenance, is reviewed. This method also includes accounting for depreciation, reliability, and maintenance schedules. This results in optimizing asset performance and life cycle considerations.

\section{Business Case Approaches}

The business case process is used in prioritization exercises and enables municipalities to make more sound decisions by comparing a series of options including doing nothing and evaluating the resulting scenario for each. A business case approach traditionally recommends the best option at the best price, or best value for money approach. The business case prioritization process can also be used as a communication or marketing tool for presentation to the town council and the public. 
Priorities can only be established when municipalities fully understand the strategic issues and risks, they are facing in respect to the design of their infrastructure. Many of these strategic issues will first emerge in the design stage.

To address these potential strategic issues and risks, municipalities in Newfoundland and Labrador should develop a process to analyze the design implications on the development and ongoing maintenance of infrastructure. Outside assistance in the form of consultants, planners, engineers, and lawyers may also support the municipality in maximizing benefits and minimizing downside risk in the development and design of municipal infrastructure.

Overall, at a high level, a process for understanding and addressing these risks can be summarized as seen in Figure 2 - Risk Assessment of Current Municipal Infrastructure:

\section{FIGURE 2 \\ RISK ASSESSMENT OF CURRENT MUNICIPAL INFRASTRUCTURE}

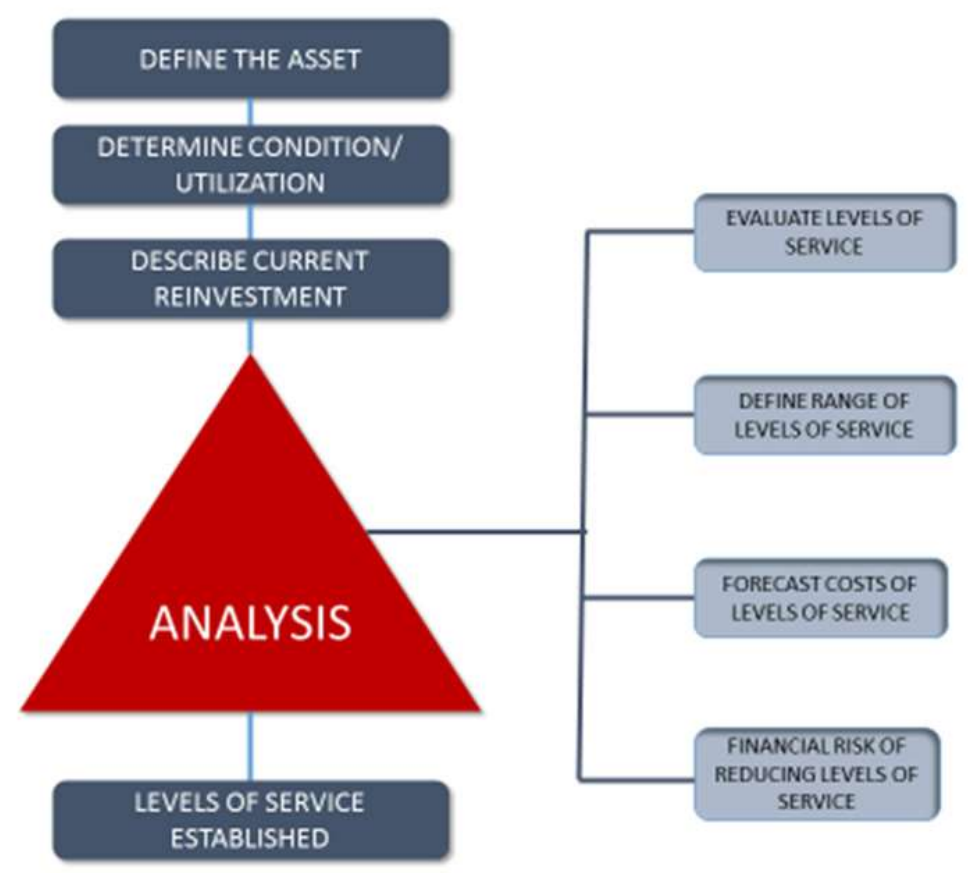

Understanding and addressing the issues and risks in the design stage of municipal infrastructure includes the following elements:

\section{Define the Asset}

Municipalities in Newfoundland and Labrador need to understand the assets that compromise their infrastructure.

\section{Determine Condition/Utilization}

Through determining the condition and utilization of their infrastructure, municipalities can apprehend how often and how it is used; both important questions in design especially as it relates to service levels/ 


\section{Describe Current Reinvestment}

From a financial standpoint, municipalities in Newfoundland and Labrador should understand how much they are currently investing in the asset that is part of their infrastructure including their initial investment as well as continuing costs for maintenance and renewal as part of the design process;

\section{Analysis}

In the analysis section of the design, municipalities should consider: evaluating levels of service, determining the range of levels of service, forecasting costs of levels of service as well as the financial (and operational) risks of maintaining a specific level of service.

\section{Levels of Service Established}

Municipalities, after going through this process of identifying risks and issues, should have a more complete understanding of the levels of service that it will need to achieve and meet to ensure success in the design, management and funding of its municipal infrastructure.

Designing municipal infrastructure is not just about following process but also ensuring that common barriers are addressed as part of meeting a municipality's strategic goals and objectives. Based on a review of the research and good practice, key barriers are identified in the design of municipal infrastructure that municipalities should be aware of including:

- Flawed initial design methodology for infrastructure systems;

- Inadequate detail review to the complexity of infrastructure planning; and

- Poor financial structures to support long-term infrastructure maintenance.

Barriers can be addressed and overcome with an adherence to good practices around the design and planning of municipal infrastructure, such as those outlined in Figure 1 and 2. Moreover, having a municipal strategic plan with a section on infrastructure will also assist in design and planning.

The design process around municipal infrastructure tends to be iterative and the level of effort in each activity might vary considerably for municipalities with differing demographics and for dissimilar types of assets. For example, the process and emphasis for establishing levels of service for transportation systems might be significantly different than for a wastewater treatment facility. As well processes will differ by municipality, however, the basic approach identified in Figure 2 should still be viewed as an appropriate good practice process to be followed in the strategic design of municipal infrastructure.

Too often important decisions around municipal infrastructure are being delayed and/or ignored owing to inappropriate planning and analysis in the design stage. More work is needed so that municipalities in Newfoundland and Labrador fully understand the implications of building/ maintenance/renewal, as well as disposal of infrastructure. Many of these implications can be fully understood when designing municipal infrastructure and have further repercussions around the management of municipal infrastructure.

\section{MANAGEMENT}

Management is usually manifest through policies and procedures. At the highest level, policies and procedures are meant to express Council's direction for guiding staff in decision making when carrying out a municipality's strategies, plans and activities. Good policies articulate clear directions, identify accountabilities, and can be consistently applied. Moreover, policies and procedures enhance public confidence as well as improve services and the municipalities' efficiency and effectiveness. When a municipality in Newfoundland and Labrador adopts a policy around its infrastructure management, it also demonstrates that it is exercising good stewardship and is delivering affordable services, while considering its legacy to future residents.

Good practice in municipal infrastructure management is primarily focused on adopting a comprehensive asset management strategy broadly defined as a set of actions that, taken together, have the lowest total cost; not the set of actions that each has the lowest cost individually.

Using an asset management strategy provides transparent, rational, and accountable cost-effective management of municipal infrastructure systems. It also provides best value for money, saving 
unnecessary cost. Moreover, an asset management policy focused on infrastructure could be viewed as a value management program at strategic and tactical levels for a municipality. Many of the good practices and thinking around asset management have emerged from the Federation of Canadian Municipalities.

According to the Federation of Canadian Municipalities, the current state of asset management planning varies among municipalities. Regardless of whether a municipality is beginning to develop a plan or reviewing an existing one, the following actions around decision and support, public engagement and external collaboration may be needed to ensure a successful outcome.

\section{Direction and Support}

- Obtain a Council resolution that directs staff to develop an asset/municipal infrastructure management plan.

- Designate a project champion within the municipal administration and another on Council.

- Establish a Working Group or Steering Committee to engage the appropriate municipal departments in the process.

- Ensure that engineering, finance, and other appropriate representatives are included.

\section{Public Engagement}

- Engage the public to help envision what the municipality will look like in the future and the infrastructure needed to support it.

- Assist the engagement process by identifying priority projects and developing costing scenarios.

- Be open to conversations about prioritization and the difficult choices that need to be made.

\section{External Support and Collaboration}

- Consider if advice from external experts would help Council to make better informed decisions on the asset management plan.

- Examine the advantages of potential partnerships with neighbouring municipalities. Partnerships could be as simple as sharing resources and bundling multiple projects into one procurement - or more complex arrangements involving consolidation of infrastructure services.

\section{An Open and Ongoing Process}

Ensure that municipal infrastructure/asset management plans are clear and available to the public.

- Monitor and report on the implementation of asset management plans at various levels.

- View asset management plans as living documents that require continuous updates and improvements.

Moreover, in the management of municipal infrastructure three important elements are necessary:

- The municipality itself - what are its strengths and weaknesses;

- The inter-relationships that municipality has; and

- Information requirements required to management municipal infrastructure.

These three important strategic elements will have an impact on a municipality managing its infrastructure. An asset/municipal infrastructure management plan therefore helps to develop the optimal approach to:

- Allocate limited budget resources effectively;

- Increase public accountability in justifying the resulting infrastructure;

- Answer questions concerning deviations in the use of all or part of the infrastructure network;

- Evaluate the performance impact and monetary impact of this deviated use; and

- Evaluate all infrastructure types and individual segments on an equitable level.

These factors are critical to the overall success of a municipality managing its infrastructure. Specifically, the key elements need to be considered as part of the existing municipal infrastructure are outlined along with the budget/funding available to manage municipal infrastructure. These elements are 
summarized in Figure 3 - Critical Success Factors in Developing a Municipal Infrastructure Plan. This plan was developed from the same sources for Figure 1.

\section{FIGURE 3 \\ CRITICAL SUCCESS FACTORS IN DEVELOPING A MUNICIPAL INFRASTRUCTURE PLAN}

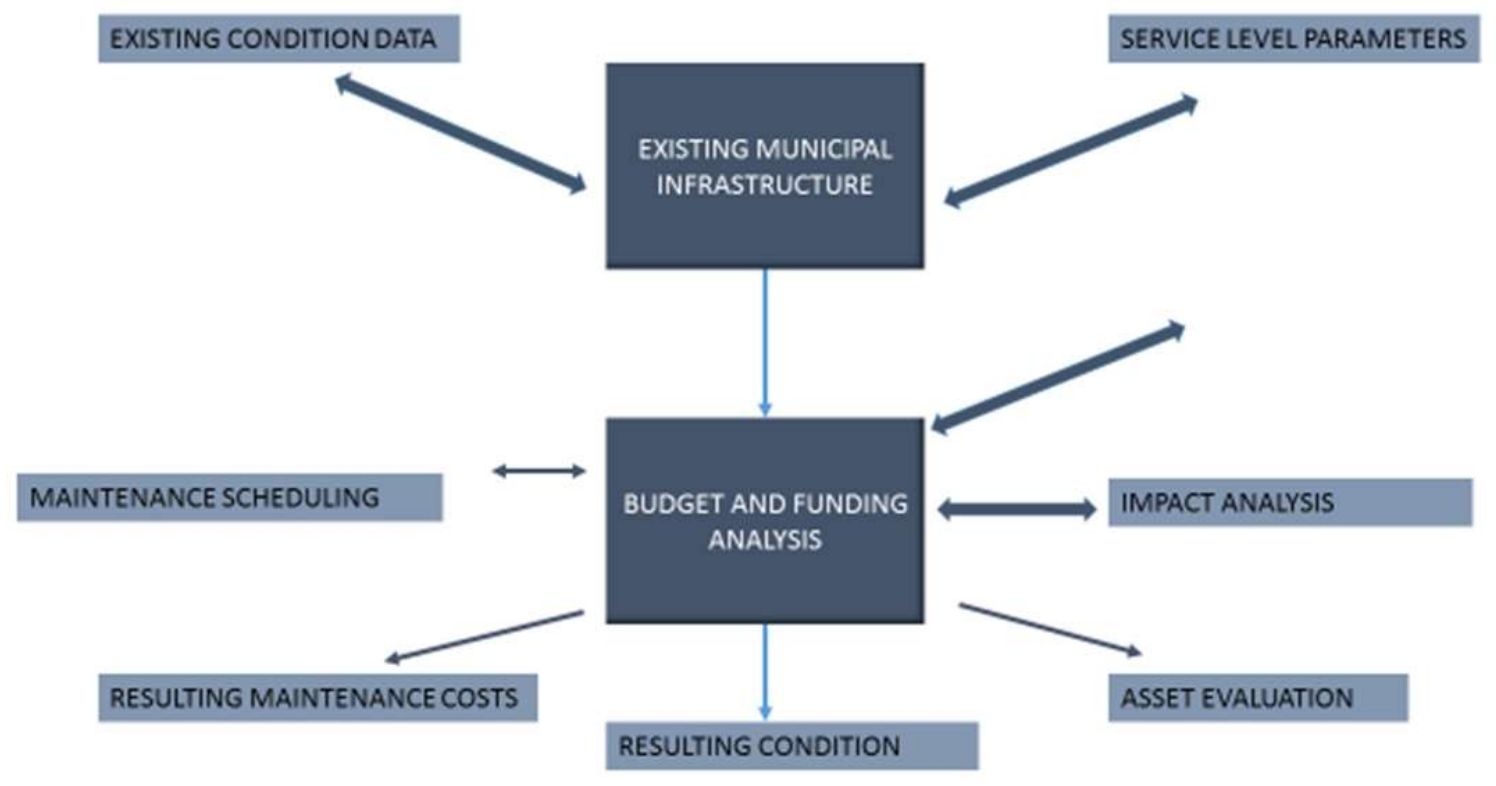

In terms of good practice, all these elements can and should be addressed in a municipal asset management strategy and plan.

Danylo \& Lemer (1998) argue that it is also important to note that a municipal asset management plan is a strategic process that states how a group of assets is to be managed over a period of time by a municipality. A detailed asset/municipal infrastructure management plan usually has the following sections:

- State of local infrastructure

- Expected levels of service

- Asset/municipal infrastructure management strategy

- Financing strategy

A well written plan should describe the characteristics and condition of infrastructure assets, the levels of service expected from them, planned actions to ensure the assets are providing the expected level of service, and financing strategies to implement the planned actions. Strategic planning and budgetary analysis then are two important elements that must be part of a municipality's approach to managing infrastructure (Vanier 2001). Both these elements, strategy, and budget, can be seen descriptively in Figure 4 - Strategic and Budgetary Approaches to Municipal Infrastructure Plan in the following figure: 


\section{FIGURE 4 \\ STRATEGIC AND BUDGETARY APPROACHES TO MUNICIPAL INFRASTRUCTURE PLAN}

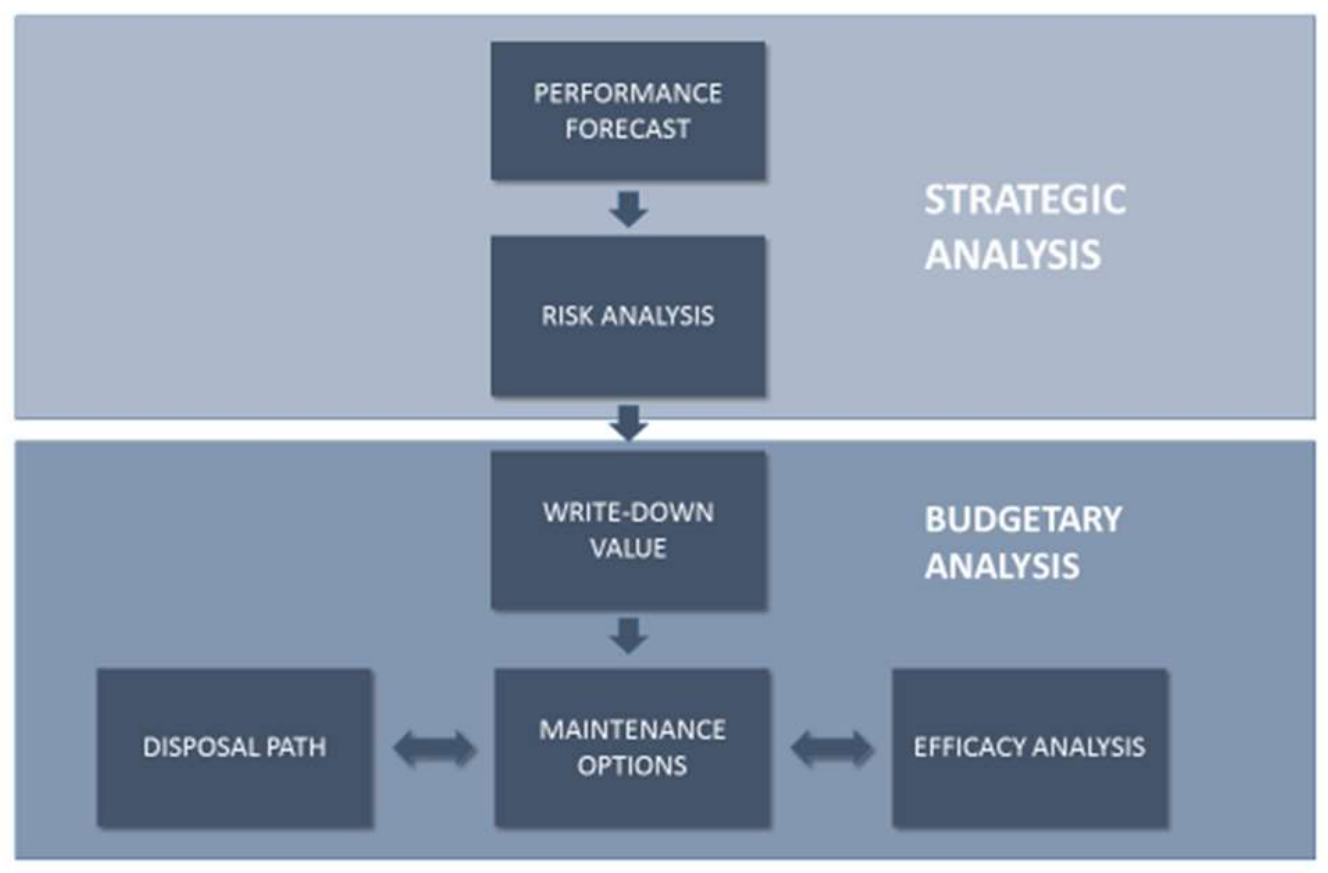

Performance and risk as well as explicit valuation and maintenance options all must be considered in the management of municipal infrastructure. Both the strategy: where do you want to go, how you want to get there and the risks of taking a particular course of action: as well as the financial analysis, how much money do we have, where can be it be best spent and the different options available, are essential elements to the effective management of municipal infrastructure. Too often it seems the strategic analysis is subsumed or forgotten in the development of the financial budget. Both strategy and financial/budget analysis need to be considered in the management of municipal infrastructure.

As with the design of municipal infrastructure, service levels are critical. A municipal asset management strategy should provide the desired levels of service in a sustainable way, while managing risk, at the lowest lifecycle cost (e.g., through preventative action) by various tactics and actions. At a tactical level, an asset management plan summarizes planned actions, includes the following.

\section{Non-infrastructure}

These solutions are actions or policies that can lower costs or extend asset life (e.g., better integrated infrastructure planning and land use planning, demand management, insurance, process optimization, managed failures, etc.).

\section{Maintenance Activities}

These activities include regularly scheduled inspection and maintenance, or more significant repair and activities associated with unexpected events.

\section{Renewal/Rehabilitation Activities}

These activities are significant repairs designed to extend the life of the asset. For example, the fixing the cracks in sidewalks can defer the need for replacement. 


\section{Replacement Activities}

These activities are expected to occur once an asset has reached the end of its useful life and renewal/rehabilitation is no longer an option.

\section{Disposal Activities}

These activities associated with disposing of an asset once it has reached the end of its useful life or is otherwise no longer needed by the municipality.

\section{Expansion activities (if necessary)}

These activities are required to extend services to previously areas not previously or expand services to meet growth demands.

\section{Procurement Methods}

These methods ensure the most efficient allocation of resources, good practice is for a number of delivery mechanisms to be considered, such as working with other municipalities to share projects and resources.

\section{Risk Assessment}

Risk assessment includes an overview of the risks associated with the asset management strategy (i.e. ways the plan could fail to generate the expected service levels) and any actions that will be taken in response.

Understanding and implementing both the strategy and tactical decisions around the management of municipal infrastructure can assist council and staff in the both short-term service levels, as well as the long-term sustainability of municipal infrastructure.

When adopting an asset management policy to manage infrastructure, municipalities should consider the following factors:

- Community infrastructure needs in the municipality;

- Capital expenditure and available funding resources, which include an equitable share from the federal/provincial government, grants from the provincial government for infrastructure projects, departmental budgets, and other sources, such as donations from donors or the private sector, loans and public-private partnerships;

- Policy options (cost-benefit) available to municipalities;

- Community involvement in selecting the most urgent priorities;

- Developmental needs and development of infrastructure;

- The vision for the municipality on infrastructure development; and

- On-going maintenance and integration of infrastructure projects.

Most of these questions are strategic rather than operational. Moreover, the management performance of infrastructure is specific to a municipality, reflective of its knowledge, technologies, and available tools, and will evolve over time. Good practice would see the management of municipal infrastructure evolving from the strategic to the operational over time and is appropriate that the responsibility for guidelines and practices should be delegated to staff. However, it is important that a municipal infrastructure/asset management policy outline long term strategic goals with processes and steps on how these goals will be achieved.

\section{FUNDING}

Although funding is an important element of the design and management process it should also be considered an essential part of municipal infrastructure in and of itself. Four reasons for considering the funding of municipal infrastructure, apart from design and maintenance, are discussed. 
First, the financing of major infrastructure projects is lumpy in nature; that is, large expenditures in one year generally preclude similar expenditures in subsequent years; addressing the long-term considerations of funding is an important strategic consideration.

Second, benefits from large infrastructure projects often extend over many years. The timeline between when and how benefits will accrue to a community has strategic implications, which may need to be reflected in the funding strategies.

Third, infrastructure is often funded from special assessments, development charges, reserves, borrowing, grants, and own source revenues, while operating expenditures are funded only from grants and own-source revenues.

Fourth, financing is critical for municipalities' needs, wants as well as the risks emerging from not having adequate levels of financing.

Financing can be understood both from an asset, as well as budgetary analysis. The approach to the management of municipal infrastructure will therefore be influenced by the performance, write-down value as well as mitigation strategies around the assets. These elements influence the budget which will depend on how a municipality decides to fund its infrastructure. This interrelationship can be seen in Figure 5 - Analyzing Municipal Infrastructure Funding.

\section{FIGURE 5}

\section{ANALYZING MUNICIPAL INRASTRUCTURE FUNDING}

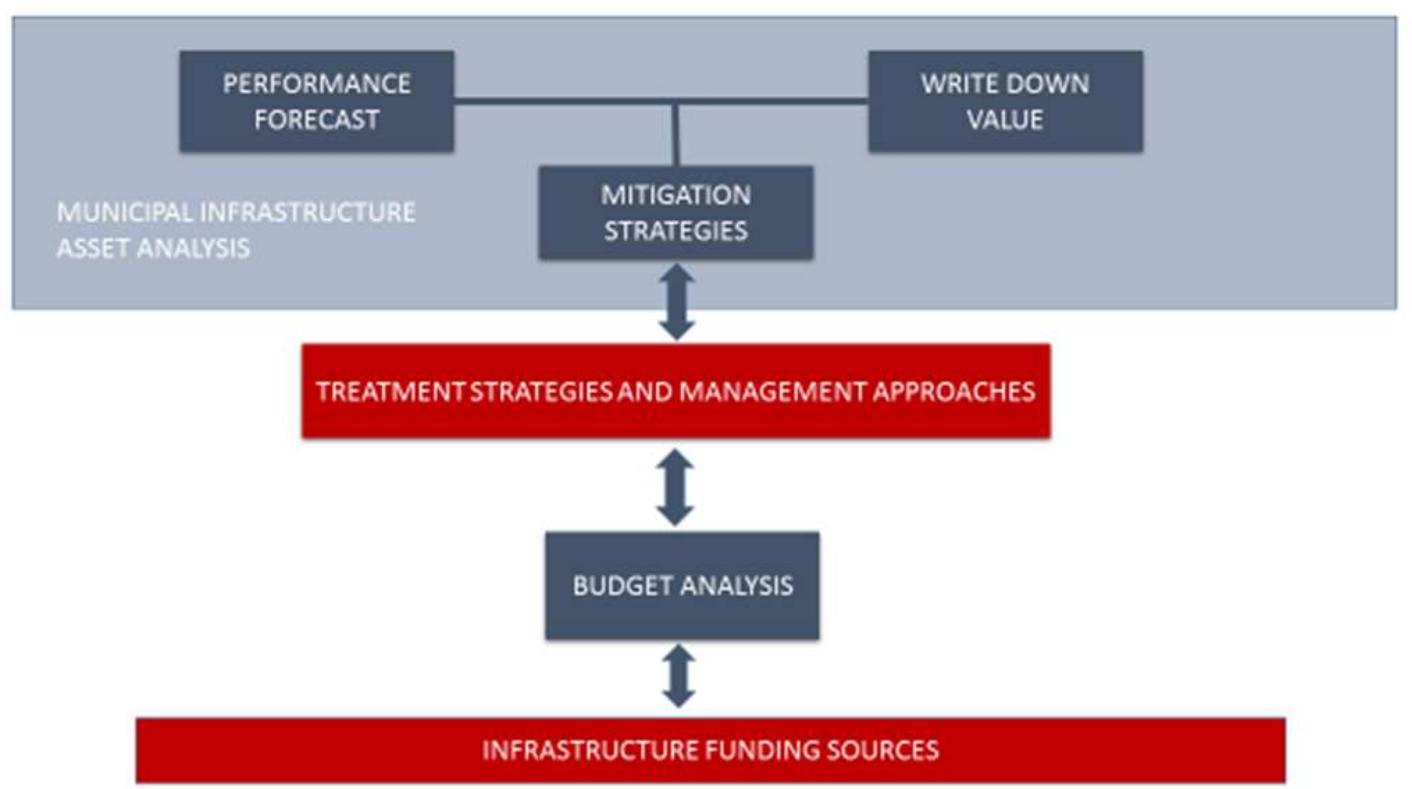

The source and sustainability of financing is the main issue that most municipalities need to address. Sources of municipal financing include government transfers, debt as well as public private partnerships.

Municipalities in Newfoundland and Labrador primarily receive grants from both the provincial and federal government. Municipal grants fall within the framework of several programs that are managed by different departments and agencies and it is, therefore, difficult to establish an exhaustive inventory. For example, since 2000 federal infrastructure transfers have mainly trickled down to municipalities in the form of the Green Municipal Fund (2000), the gas-tax-sharing arrangement (2005), the Building Canada Plan (2007), and the stimulus-spending program (2008), in an effort to support municipalities in infrastructure maintenance and development. As well, there have been many forms of government transfers and grants over the years. 
Municipal governments, including those in Newfoundland and Labrador, have already managed to extract a great deal of infrastructure funding out of higher levels of governments. Yet, federal-provincial government funding is a seriously flawed means of funding local infrastructure.

The reason for this flaw is that money gathered at the federal and provincial level is placed in municipal coffers, breaking the chain of political accountability for the outcomes. This alters the spending priorities of municipal governments as they are inclined to favor those projects with federal or provincial subsidies attached. As a result, such subsidies lower the political costs allowing municipalities in Newfoundland and Labrador to maintain artificially low taxes for their constituents by spending federal or provincial tax revenue. These projects come at a discount to municipalities, but not their constituents who will ultimately pay through federal or provincial income taxes. Most importantly, this kind of funding results in unpriced infrastructure access and contributes to the over-usage of infrastructure. Funding municipal infrastructure through government grants is therefore a complicated area for most municipalities and is difficult to sustain the medium to long term.

Debt financing for current infrastructure-capital spending is another option, although it requires future revenues to finance the payment of interest and debt principal. Good practice sees municipal governments using debt finance to fund infrastructure that enables economic, community development and productivity, resulting in higher incomes in later years, less volatile taxes over time, and financing burdens more equally distributed across generations. However, there is also a tendency for governments to sometimes use debt finance for non-capital and capital spending to push costs onto future generations who have no voting power when current decisions are being made.

Privatization would see a municipality seeing a private entity assume the funding of a municipal infrastructure asset. The private entity, therefore, takes much (if not all) the risk in developing the funding of an asset and a result can charge rents on the use of that municipal infrastructure. For the most part, privatization works very effectively as a risk reduction mechanism from a financial standpoint for a municipality but has psychological barriers that would make it a less favorable strategy especially in a Newfoundland and Labrador context. An alternative to privatization is a public-private partnership (PPP). The PPP enables a private company to enter into an agreement with a government to build infrastructure partially financed by private capital. The private company might also administer the project after its completion, including maintenance and operation. PPPs are commonplace in the United Kingdom, where they first developed, and are increasingly used across Canada. PPPs have been used to build transport networks, water-treatment facilities, and other public infrastructure in Canada.

PPPs are successful if there is a proper allocation of returns and risks. If a government guarantees losses or low rates of return, the private producer can take on too much risk, leading to cost overruns. Limits on high rates of return for risky investments can also undermine incentives for private firms to take on best practices. Without proper contract design, PPPs can underperform or fail.

Apart from these three external sources of funding, there are also internal sources available to local government. Rural municipalities, as seen in Newfoundland and Labrador, towns and smaller cities tend to rely more on local taxes, user fees and grants than on borrowing, partly because borrowers view them as higher risk than larger cities, thus raising their borrowing costs. Under the benefits-based model of municipal finance, financing capital spending from operating revenues is desirable to the extent that benefits accrue to current users.

User fees are arguably fair, since they are payments made by those who demand additional public services. They are also efficient to the extent that those individuals demanding the public service must pay for it. Yet, generally Canadian provincial and municipal governments have been reluctant to fund infrastructure through user fees.

There are likely several reasons for the substantial political resistance to user fees, and the potential political costs have contributed to a general reluctance on the part of governments across Canada to embrace a broader use of user-pay funding models. Reasons include:

- User fees as a proportion of income fall as a person's income rises (analogous to a regressive tax), reflecting the extent to which the public service is a necessity; 
- User fees are assessed on a cost-recovery basis by governments that do not feel the competitive pressures to achieve efficiencies to keep costs as low as possible; and

- Users of infrastructure have made personal consumption decisions, including investments in personal transport and the location of housing, based on existing arrangements. As such, charging for services and infrastructure previously unpriced, such as roads, may be viewed as unfair, as it would change the (currently underpriced) cost of commuting to the core.

Municipal governments can address these issues with various arrangements. In the case of user fees charged to low-income households, personal or property tax relief through an income tax credit could offset any impact on low-income households. Efficiency can be addressed through good governance and public consultation.

Financing capital projects through funds set aside for capital spending is the reverse of financing through borrowing. Reserves, financed from general taxes, tend to violate the principle of intergenerational equity because current users and taxpayers pay for capital that future generations will use.

Most large municipalities and many smaller ones impose a specific dollar value per lot on developers to finance the off-site capital costs of new development. Developers are generally responsible for on-site services, such as local roads, sidewalks, and street lighting.

The most efficient development charges are those that vary by type of property (residential, commercial, or industrial), neighbourhood and distance from source of supply, so that each charge captures the extra cost of capital assets required to service the new or additional growth. Most Canadian municipalities, however, do not impose variable charges.

\section{FUNDING CHALLENGES AND TRENDS}

In Canada, the three main sources of municipal revenue are the property tax $(53 \%)$ followed by user fees $(22 \%)$ and provincial transfers $(17 \%)$. Most transfers are conditional (specific purpose) transfers from provincial governments. The largest conditional transfers are for transportation, water and sewage treatment and social services, particularly Ontario where funding for social services has been downloaded to municipalities. In addition to these transfers, various themes, and future challenges around the financing of municipal infrastructure emerge as outlined in following tenets as enumerated by Heuton (2010).

\section{Shared-Cost Grants}

In general, Canadian cities rely heavily on Own Source Revenues $(83 \%)$ to support the more than $\$ 58.5$ billion of local government spending that occurs each year. Although, cities depend on Property Taxes $(52.7 \%)$ as a revenue source, there has been a greater emphasis placed on increasing user fees. Alternative revenue sources have become an important component of balancing city budgets since provincial governments started cutting grant transfers to local communities in the 1990s. However, economic vulnerabilities in Newfoundland and Labrador, with the complexities associated with municipal infrastructure, means that shared-cost grants are an inescapable necessity.

\section{Increased Dependence on User Fees}

It is essential that users asked to bear the cost of infrastructure use are rewarded with localized and tangible benefits. Broader use of pricing for infrastructure would also create predictable and dedicated revenue streams that would allow municipalities to responsibly take on additional debt to invest in much needed municipal infrastructure.

Slack \& Kitchen (2006) contend that municipal infrastructure should also be financed, as far as possible, based on benefits received. The underlying principle of benefits received is straightforward: those who benefit from local infrastructure and the services it provides should pay for it (Duff 2003). 


\section{Development Charges}

Uniform development charges fail to achieve an efficient allocation of resources because properties that cost less to service subsidize properties that are more expensive to service. Switching to a charge that varies by property or neighbourhood according to servicing cost would lead to a better matching of payment for services with the capital cost of the assets provided and an improved allocation of local resources.

\section{Greater Use of Public-Private Partnership and Alternative Service Delivery Models}

This process could alleviate some financing concerns by passing the burden onto the private sector, albeit with a role for the government in the form of price regulation or monitoring. At the same time, recognizing the role of non-for-profit organizations in service delivery should be considered by municipalities especially in Newfoundland and Labrador where that sector is particularly strong. The importance of civic society organizations in services is increasing recognized but insufficiently understood. Do these organizations crowd out municipally provided services, as financially strapped local governments opt out of services in sectors in which they believe not-for-profit organizations operate? Or do not-for-profit organizations act as a complement to municipal government services?

\section{Evidence Based Decision-Making}

Generating more reliable data on various dimensions of infrastructure finance is crucial. It is especially important to have basic information on such items as the extent of municipal infrastructure spending and the extent of a municipality's assets, generated via a uniform methodology that allows multi-year comparisons of municipality behavior to be made.

\section{Incorporating Recent Approaches to Valuing Risky Investments in Infrastructure Project Appraisal}

Modern finance theory has made important innovations in evaluating private investment projects. These innovations may provide useful insights in evaluating public projects, or social benefit-cost analysis. Municipalities should establish multi-year capital budgets, adopt fund accounts wherever possible, use accrual accounting with an annual measure of depreciation or capital replacement costs, and develop and document asset management programs.

Financing, both capital budgeting and ensuring long-term financial sustainability, is critical in the design, management, and funding of municipal infrastructure. Ensuring that financial decisions incorporate appropriate time and risk considerations is also critical. However, the most essential thing that municipalities can undertake, especially in Newfoundland and Labrador, is viewing financing around municipal infrastructure as a strategic concern, not just an operational one around what government transfers are available, is critical for long-term success.

\section{RECOMMENDATIONS}

Due to the magnitude of the infrastructure deficit, along with the dramatic cost of infrastructure renewal in Newfoundland and Labrador, a strategic approach to the design, management and funding of municipal infrastructure must be undertaken. Apart from these strategic considerations, including intergovernmental relations, regional government and improved political decision making, along with other considerations and lessons that can be learnt in the design, management, and funding of municipal infrastructure (Vanier, Lacasse \& Parsons 1996).

\section{Consultation/Communication}

Consultation and communication around the design, management and funding of infrastructure levels can occur in an informal manner, particularly for smaller municipalities. In larger municipalities, the use of focus groups, open houses, and surveys is more likely to be the norm. 


\section{Municipal Goals/Strategic Alignment}

There needs to be a clear understanding of municipal goals/strategic alignment and the municipality's mission objectives. The design, management and funding of municipal infrastructure is very much a financial concern. Having municipal goals and strategy aligned to the design, management and funding of infrastructure is essential for sustainable financing and reflects whether elected officials and the administration clearly understand the community's expectations especially around service levels.

\section{Financial Considerations}

Financial considerations are paramount in the decision-making process, necessitating the establishment of priorities in close consultation with stakeholders, such as the provincial government, regional partnerships, and representatives of the municipality.

\section{Inventory of Municipal Infrastructure}

A complete inventory of all infrastructure facilities with a detailed condition assessment of each asset which comprises a municipality's infrastructure should be undertaken. This will enable the development of optional repair and rehabilitation strategies with the limited budgets currently available.

\section{Regional Infrastructure Partnerships}

It is also a good practice in the design, management, and funding of municipal infrastructure to have a regional asset management plan with the following goals:

- Evaluate water supply and demand for long-term system capacity,

- Evaluate economies of scale to determine the feasibility of the regional approach to municipal infrastructure distribution and infrastructure,

- Investigate management partnerships,

- Establish a long-term financial structure to fund capital improvement programs and

- Establish a development process for land-use design strategies among local jurisdictions and developers, thus reducing competition between potentially competing interests.

\section{Intergovernmental Relationships}

Intergovernmental agreements, regional governments, good neighbour agreements, as well as strategic partnership agreements are therefore key instruments for a municipality to establish partnerships to control and regulate infrastructure design and land development.

\section{Decision-Making and Investments Planning}

Municipalities need to develop criteria/tests for balance between political, social, economic, and environmental benefits/risks in the design, management, and funding of municipal infrastructure. Part of this will include defining levels of service in the context of decision making and investment planning around municipal infrastructure. As well, municipalities should develop high level benchmarks [indicators, reference points] for planning decisions including both quantitative and qualitative criteria.

\section{Municipal Financing}

Municipal financing is probably the most problematic area that municipalities needs to consider in the design, management, and funding of municipal infrastructure. Specific considerations for the financing of municipal infrastructure include the following:

- Establishing the conditions under which borrowing can take place

- Consider the ability of municipalities with demographic challenges to generate own-source tax revenues, especially from the property tax, as it may often be quite limited.

- User charges can be a useful source of revenues and can also have positive impacts on resource allocation, but their record is mixed. Attitudinal barriers around user fees are significant. 
- Public private partnerships with both the private and not-for-profit sectors must pay attention to the overall benefits to the municipality and to its partners.

- Ensuring that the financing and funding of infrastructure is tied to a municipality's strategic plan.

An asset/infrastructure management plan should also include some direction for staff to develop guidelines and practices in managing, financing, operating current assets and planning for future assets and the delivery of services. Moreover, the development of these asset management strategies and plans are essential to accomplishing long-term goals. Finally, the plan should require operational plans to reflect the asset management plans.

\section{CONCLUSIONS}

Municipalities in Newfoundland and Labrador should develop a process to analyze the design implications on the development and ongoing maintenance of infrastructure. Outside assistance in the form of consultants, planners, engineers, and lawyers may also support the municipality in maximizing benefits and minimizing downside risk in the development and design of municipal infrastructure.

Many municipalities in Canada, including Newfoundland and Labrador, are also facing new pressures or increased complexity in infrastructure decision making. Whether to rebuild a town hall, invest in new fire equipment or build a new park in a town with an aging demographic all are examples of the dilemmas emerging. Due to these dilemmas and other challenges, design, management, and financial issues continually arise. Moreover, relatively 'new' issues have also emerged due to increased public concern, climate change, societal expectations, and government regulatory requirements such as water and waste management. Overall, issues/concerns around infrastructure have increased significantly for municipalities in Newfoundland and Labrador as well as elsewhere in Canada including:

- Delegating of responsibility for several services formerly managed by federal, regional, or provincial authorities to municipalities. This is being done while access to new funding has not increased in proportion to infrastructure needs;

- Concern for public health and safety;

- Concerns around waste management;

- Concern for road traffic congestion and speeding;

- Concern for aging populations and ease of access to services;

- Concern for aging infrastructure supporting municipalities;

- Concern for air and water quality, watershed integrity, biodiversity decline, species at risk, and maintaining green spaces, natural areas and terrestrial wildlife habitat;

- Implications of the growing number of satellite communities and commuters;

- An expectation of transparency and accountability in government spending; and

- Regulatory requirements such as senior government requirements for waste management.

Typically, these concerns and the infrastructure that addresses them is seen as an operational issue.

Understanding the difference between the operational and strategic concerns around the design, management, and funding of municipal infrastructure is an important consideration in the development of good practice and ensuring relevant communities both now and in the future. Moreover, in Newfoundland and Labrador, with the challenges of an aging demographic, volatility around government finances and the unpredictability around a resource based economy, understanding the strategic issues behind the design, management and funding of municipal infrastructure is a critical success factor for the province's future.

These findings from the research are that the reasons for success/failure as to the design, funding, and municipal infrastructure are often unclear. In particular, the role of the municipality's strategic plan in determining success/failure is not well understood and is often neglected. In Newfoundland and Labrador, disconnects exist between the design, management and funding of municipal infrastructure and the services received by users. This has produced too much infrastructure in some of the services that 
municipalities provide and too little in other sectors. For the most part, municipalities in Newfoundland and Labrador fail to consider the design, management, and funding of municipal infrastructure as a strategic concern. Municipalities generally fail to include all costs (asset replacement costs and a variety of opportunity costs) in the design and management of infrastructure. This has led to a demand for services and, subsequently, a demand for physical infrastructure that is not efficient, optimal or strategic for municipalities within the province.

Municipalities in Newfoundland and Labrador should ensure effective design, management, and funding practices before undertaking any major infrastructure program. Undertaking these practices will ensure both short- and long-term success when considering the role of municipalities in the design, management, and funding of municipal infrastructure in Newfoundland and Labrador. The long-term goal of a mature infrastructure asset-management system is to provide repeatable and auditable evaluation of infrastructure condition and investment needs. Municipalities should also establish specific assetmanagement plans, based on infrastructure life-cycle assessments that consider rates of deterioration and community-service levels.

Overall, there are multiple dimensions by which the design, management and funding of municipal infrastructure can be evaluated, and success/failure is often different across these dimensions. One of the continual themes that emerged from the review of research and best practice included the importance of data around making strategic decisions in the design, management, and funding of municipal infrastructure. However, the data necessary to conduct an evaluation of municipal infrastructure are often poor, even nonexistent. This means that even a simple evaluation such as a cost/benefit analysis of a decision around municipal infrastructure is often not done adequately. Data problems are often the overriding issue when doing the analysis around the design, funding and management of municipal infrastructure.

The reasons for success/failure as to the design, funding and municipal infrastructure are often unclear. In particular, the role of the municipality's strategic plan in determining success/failure is not well understood and is often neglected. As a result, in Newfoundland and Labrador, we found that there is currently a disconnection between the design, management and funding of municipal infrastructure and the services received by users. This has produced too much infrastructure in some of the services that municipalities provide and too little in other sectors. For the most part, municipalities in Newfoundland and Labrador fail to consider the design, management, and funding of municipal infrastructure a strategic concern. They generally fail to include all costs (asset replacement costs and a variety of opportunity costs) in the design and management of municipal infrastructure. This has led to a demand for services and, subsequently, a demand for physical infrastructure that is not efficient, optimal or strategic for municipalities within the province. Municipalities in Newfoundland and Labrador should ensure effective design, management, and funding practices before undertaking any major infrastructure program. Undertaking these practices will ensure both short- and long-term success when considering the role of municipalities in the design, management, and funding of municipal infrastructure in Newfoundland and Labrador.

\section{REFERENCES}

Alm, J. (2015). Financing Urban Infrastructure: Knowns, Unknows, and a Way Forward. Journal of Economic Surveys, 29, 230-262. doi:10.1111/joes. 12045

Bazel, P., \& Mintz, J. (2014). The Free Ride is Over: Why Cities, and Citizens, Must Start Paying for Much-needed Infrastructure. SPP Research Paper, 7-14.

Canada's Infrastructure Report Card. (2016). Retrieved from http://www.canadainfrastructure.ca/downloads/Canadian_Infrastructure_Report_2016.pdf

Curtis, F.A., \& Molnar, G.S. (1997). A municipal infrastructure management systems model. Canadian Journal of Civil Engineering, 24(6), 1040-1049.

Danylo, N., \& Lemer, A. (1998). Asset Management for the Public Works Manager: Challenges and Strategies. Findings of the APWA Task Force on Asset Management. 
Developing Levels of Service. (2003). Federation of Canadian Municipalities and National Research Council, Issue No. 1.1.

Duff, D.G. (2003). Tax policy and global warming.

Edwards, T.L. (2007). Sustainable Intergovernmental Agreements: A Case Study of Civil Infrastructure Design and Regional Cooperation. Public Works Management \& Policy, 12(1), 370-377.

FMC. (2003). Planning and Defining Municipal Infrastructure Needs.

Grace, J. (2013). Building from the Ground up: Funding the Infrastructure Deficit in Manitoba. Man. LJ, $37,399$.

Gosselin, G., \& Kalynchuk, D. (2002). National Guide to Sustainable Municipal Infrastructure: Innovations and Best Practices. Annual Conference of the Canadian Society for Civil Engineering.

Halfawy, M.R. (2008). Integration of municipal infrastructure asset management processes: challenges and solutions. Journal of Computing in Civil Engineering, 22(3), 216-229.

L'heureux, J. (1986). Le Partage des Pouvoirs et les Municipalités. In Les Relations Intergouvernementales, edited by R. Simeon \& D. MacDonald (205-246). Ottawa: Commission Royale sur l'Union Économique et les Perspectives de Développement du Canada.

Heuton, G. (2010). Fiscal Austerity and Urban Innovation: The Challenges Facing Canadian Cities. Canadian Political Science Association Annual Meetings, Montreal. Retrieved from

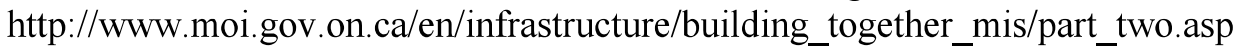

Kitchen, H.M. (2006). A state of Disrepair: how to fix the financing of municipal infrastructure in Canada (p.11). CD Howe Institute.

Lounis, Z., Vanier, D.J., Lacasse, M.A., \& Kyle, B. (1998, October). Effective decision-making tools for roofing maintenance management. In First International Conference on New Information Technologies in Civil Engineering, 425-436.

Mehiriz, K., \& Marceau, R. (2014). The Flypaper and Asymmetric Effects of Intergovernmental Grants to Quebec Municipalities. Public Budgeting \& Finance, 34(1), 85-102.

Mirza, M.S., \& Haider, M. (2003). The state of infrastructure in Canada: Implications for infrastructure planning and policy. Infrastructure Canada, 29(1), 17-38.

Slack, E., \& Kitchen, H. (2006). Trends in Public Finance in Canada. Institute for Municipal Finance, Toronto University, Toronto. Retrieved from http://www.utoronto.ca/mcis/imfg/resources.htm\#pub

Vanier, D.D. (2001). Towards Sustainable Municipal Infrastructure Asset Management. Retrieved from www.irc.nrc-cnrc.gc.ca

Vanier, D.D. (2001). Why industry needs asset management tools. Journal of Computing in Civil Engineering, 15(1), 35-43.

Vanier, D.J., \& Danylo, N.H. (1998, September). Municipal infrastructure investment planning: Asset management. In Innovations in Urban Infrastructure Seminar of the APWA International Public Works Congress (25-39).

Vanier, D.J., Lacasse, M.A., \& Parsons, A. (1996). Using product models to represent user requirements. CIB REPORT, pp. 511-524.

Vanier, D.J., \& Rahman, S. (2004). A Primer on Municipal Infrastructure Asset Management. Municipal Infrastructure Investment Planning (MIIP).

30 Journal of Applied Business and Economics Vol. 22(8) 2020 